\title{
Pre-Employment Testing - Prediction Of Employee Success And Legal Issues: A Revisitation Of Griggs V. Duke Power
}

Martin Carrigan, (E-mail: carrigan@findlay.edu), University of Findlay

\begin{abstract}
Pre-employment testing has become one of the fastest-growing tools used to select successful employees within organizations. A variety of testing tools are at the disposal of Human Resource managers and hiring managers. Testing of employees has developed since the time of Sigmund Freud, and testing entered the legal arena with the seminal case of Griggs v. Duke Power. Ever since the Griggs case, "tests" need to be "relevant" and "valid" when given in the employment context, and left the burden of proof on the employer to demonstrate that its employment practices were not discriminatory, and that any disparate effects were clearly justified by the business. Since the Griggs case, employers have developed tests that legally comply with the letter of the law, but may violate the spirit of the law by still permitting illegal discrimination. This paper looks at recent case law and draws a conclusion.
\end{abstract}

\section{INTRODUCTION}

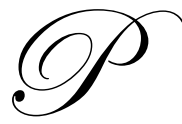

re-employment testing has become one of the fastest-growing tools used to select successful employees within organizations. A variety of testing tools are at the disposal of Human Resource managers and hiring managers.

Tests such as cognitive tests measure not only learning aptitude but also test for an applicant's ability to apply learned concepts to new situations within the workforce that the applicants may encounter during day-to-day work activities. Personality tests can measure certain responses such as conscientiousness, stress-coping skills, and anger management.

Engaging in pre-employment testing methods is of utmost importance in today's workforce. First, Human Resource managers and hiring managers want to select the most qualified candidates to fill open positions within their organizations because the most qualified candidates' job performance is a direct reflection on the hiring managers. Secondly, recruitment and hiring costs are excessively high for organizations in today's workforce, and Human Resource managers and hiring managers cannot afford to use organizational funds negligently. Thirdly, negligent hiring practices may lead to unnecessary lawsuits filed against organizations in the long term.

Pre-employment testing is a vital tool that will protect organizations by allowing them to analyze testing measures and have the necessary tools to make good sound employment hiring decisions.

\section{HISTORICAL USES OF TESTING}

\section{Early History}

Although pre-employment testing has been used within the workforce for over a century, the testing methods utilized today have evolved and improved from its humble beginnings before World War II. For instance, Sigmund Freud pioneered the psychiatric link with personality traits during the turn of the century. His scientific studies involving the science of personality was among the first endeavors conducted in researching this type of phenomena 
that was later coined psychoanalysis. Two colleagues that studied under Freud, Alfred Adler and Carl Jung, began their intellectual scientific studies into this strange phenomena with Freud during the turn of the century, and in 1911 and 1912, set out on their own to further their research into this mysterious area of science.

Alfred Adler's system which became known as individual psychology, focused on the psychological criteria that could dramatically affect and improve areas of human life such as family life and dynamics, schooling behaviors, workplace behaviors, the abolishment of war and poverty. Carl Jung's system, which focused more on mythology, fairy tales, comparative religion, and mysticism, formed his scientific beliefs on psychoanalytical behaviors stemming from not only spiritual feelings, but also experimental design as important indicators that influenced human behavior and human needs.

During the Great Depression, behaviorist John B. Watson's research focused on how positive/negative conditioning affects the human personality. After the Great Depression, motivational theorist, Abraham Maslow, focused his research on psychodynamic and behaviorist viewpoints in how human behavior falls within a pyramid of core needs, goals, satisfactions, values, and frustrations known as his Hierarchy of Inborn Needs.

After World War II, Dr. Benjamin Spock wrote several books pertaining to child rearing and focused his psychological studies on how child rearing determines how individuals develop during the maturation process in becoming adults.

Through all of this research in the psychological sciences, these men were able to push through this forbidden zone of science and establish valid and vital research that proves how human beings relate to their environment, how they respond to various stimuli, and how they mature and grow emotionally throughout their adult lives, very important indicators of future job performance.

Through the scientific findings of Sigmund Freud, Alfred Adler, Carl Jung, Dr. Benjamin Spock, and Abraham Maslow, psychological testing techniques began to be used within the workplace in order to determine how personality traits and psychological behaviors interact. These indicators inform employers how applicants react to certain stimuli, handle anger management, how well applicants work in team environments, and how well applicants cope within stressful settings.

As Mel Kleiman states in his book Hire Tough-Manage Easy "The most important factor is how closely the applicant's personality matches the job - attention to detail, working with people, assertiveness, and competitiveness, for instance. People tend to do better at things that come naturally and that they enjoy doing." ${ }^{1}$ Although skills testing is very important in determining an applicant's cognitive abilities in performing within a particular job, personality testing and psychological testing methods are just as vital in determining how an applicant will react to certain stimuli within the workplace, how that applicant will work in a team environment, and how well that applicant will perform under stress. These indicators are not as easily discovered through more conventional cognitive skills testing methods.

The Carnegie Institute of Technology in their Applied Psychology Division and a year later in their Bureau of Salesmanship Research first used psychometrics, the study and science of personality, in the workplace in 1915. This bureau was originally created to conduct research through scientifically selecting salespeople through personality testing.

Simultaneously at this time during World War I, the United States Military also began utilizing personality testing to weed out applicants not suitable for combat. Also at this time, the United States Military began utilizing pre-employment testing methods popularized by the Bureau of Salesmanship Research to predict job performance and job success.

In addition, in 1916, the first American police department utilized pre-employment psychological testing techniques in their recruitment and hiring process. In addition, the law enforcement industry, more than any other 
industry, has utilized pre-employment psychological testing methods to identify suitable and unsuitable job candidates for the police force. ${ }^{2}$

\section{Modern Era Of Testing}

By the 1920's and 1930's paper and pencil personality tests were established in order to measure personality and to predict job performance. Written tests such as Gordon Allport's Ascendance-Submission Test, and the Bernreuter Personality Inventory, were used to predict job performance of factory supervisors, nursing students, and salespeople. By the 1940 's, the leading personality test administered - the Minnesota Multiphasic Personality Inventory, became the most widely-acclaimed pre-employment test which was used for decades to come.

At the onset of World War II, standardized pre-employment testing began to experience huge spurts of growth as the United States Military utilized psychological testing techniques as a requirement for drafting soldiers into the military. These tests focused on cognitive abilities and intelligence and were considered the earliest kind of pre-employment/pre-selection testing methods to be used in personnel selection. ${ }^{3}$

In addition, by the time President Lyndon B. Johnson's “Great Society" legislative program began, standardized pre-employment testing methods had reached unprecedented levels.

During the onset of the 1970's, personality and pre-employment testing came under fire when the Civil Rights Act of 1964 and the Equal Employment Opportunity Commission (EEOC) shed doubt on the validity of preemployment testing arguing the validity of these testing methods could compromise equal opportunity employment and could challenge discriminatory issues in pre-employment selection. However, by the late 1980's and 1990's, preemployment testing made a comeback, as a model of human personality labeled the Big Five Model, which highlighted human characteristics such as neuroticism, extraversion, conscientiousness, agreeableness, and openness and experience became widely referenced. This model shed light on how important human understanding of personality and psychological behaviors was within the American workforce. This model is highly regarded and utilized today among many organizations in their pre-selection processes.

\section{New Era In Testing Concepts - Griggs v. Duke Power Co.}

Perhaps the seminal case in this area is Griggs v. Duke Power Company, 401 U.S. 424 (1971). In that case the plaintiff was Willie Griggs an African-American employee of Duke Power Company. He filed a class action on his own and also on behalf of several fellow African-American employees. All the employees worked at Duke Power's Dan River Steam Station, a power generating facility located at Draper, North Carolina.

At the time the lawsuit was filed, Duke had 95 employees at the Dan River Station, 14 of whom were African-American, and 13 of which filed the lawsuit. Griggs challenged Duke's "inside" transfer policy, requiring employees who want to work in all but the company's lowest paying Labor Department to register a minimum score on two separate aptitude tests in addition to having a high school education. Griggs claimed that Duke's policy discriminated against African-American employees in violation of Title VII of the 1964 Civil Rights Act. On appeal from a district court's dismissal of the claim, the Court of Appeals found no discriminatory practices. The Supreme Court granted certiorari.

The question presented to the Court was the following: Did Duke Power Company's intradepartmental transfer policy, requiring a high school education and the achievement of minimum scores on two separate aptitude tests, violate Title VII of the 1964 Civil Rights Act? In other words, were the required tests both relevant and valid?

After noting that Title VII of the Act intended to achieve equality of employment opportunities, the Court held that Duke's standardized testing requirement prevented a disproportionate number of African-American employees from being hired by, and advancing to higher-paying departments within, the company. Neither the high school graduation requirement nor the two aptitude tests was directed or intended to measure an employee's ability to learn or perform a particular job or category of jobs within the company. 
The Court concluded that the subtle, illegal, purpose of these requirements was to safeguard Duke's longstanding policy of giving job preferences to its white employees. Ever since that decision, "tests" need to be "relevant" and "valid" when given in the employment context.

The Griggs decision clearly left the burden of proof on the employer to demonstrate that its employment practices were not discriminatory, and that any disparate effects were clearly justified by the business. Later Supreme Court decisions in Wards Cove Packing Co. v. Atonio, 490 U.S. 642 (1989) and Price Waterhouse v. Hopkins, 490 U.S. 228 (1989) shifted the burden of proof back to the plaintiff.

In the Civil Rights Act of 1991 (Pub. L. 102-166), as enacted on November 21, 1991, which amended the 1964 Civil Rights Act, the burden of proof was once again changed to require a prima facie showing by the plaintiff, with the burden then shifting to the defendant company to demonstrate that any adverse employment decision, with or without testing, must be supported by reasons other than discrimination. The law remains in that stance today.

\section{Modern Development Of Testing After Griggs}

During the twenty-first century, organizations today have many challenges that must be addressed when recruiting and hiring new employees. Strategic goals of the organization must be fulfilled in order for that organization to thrive and grow in a dynamic working environment. Today's hiring challenges and employer liability has made pre-employment testing a crucial part of any organization's hiring process. The effectiveness and accuracy in choosing the right employees within the recruiting and hiring process is vital in achieving the organization's strategic goals, as well as minimizing employer liability. As a result, pre-employment testing has shown that the results provided are crucial in the recruitment and hiring process.

Employers today require flexible hiring strategies that enable the organization to compete against their competition and remain cost-effective in their hiring selections. As Max Messner states in his book The Fast Forward $M B A$ in Hiring, "What's changing is the mindset that is now driving the hiring process, as well as strategies that companies are adopting to fill their staffing needs....finding individuals who meet the requirements of a "position" is out of step with the challenges of today's business environment. It's too inflexible. It severely limits a company's ability to respond effectively to the changing dynamics of both the marketplace and the workplace." 4

As a result, a new paradigm of hiring strategies is being implemented within organizations. Hiring strategies that incorporate a variety of pre-employment testing strategies to ensure efficient and effective hiring procedures and practices are fully being executed in today's hiring environment.

Smart hiring decisions are based upon efficient and highly effective pre-selection and hiring processes. Because of the importance in selecting the best employees for the job, the pre-employment selection process must be a highly thorough and strategic in order to select the best candidates for hire. When incorporating a highly effective recruitment process, organizations must engage in getting the most relevant information from applicants at the time those applicants are invited in to fill out applications for employment. By having a highly effective pre-employment process, Human Resource managers and hiring managers can engage in employee selection that will help them make good, sound employment decisions. A highly effective pre-employment process is one that encompasses a thoroughly complete application that asks all the pertinent questions about contact information, education, and experience information. In addition, a highly effective pre-employment process encompasses a well-balanced reference/background check process, and effective pre-employment testing methods. These tools will enable organizations to fully narrow down the skill sets, qualities, values, and cognitive abilities necessary for an applicant to fulfill the job requirements needed to be a successful performer within the organization. 


\section{PURPOSES OF TESTING}

In addition, according to Dianna Podmoroff, in her book How to Hire, Train, and Keep the Best Employees for your Small Business "Research from the Richard Ivey School of Business in London, Ontario, shows that nearly one-quarter of the people hired by the traditional methods of interviewing and reviewing resumes will fail. These tried-but-not-true methods do not predict or identify high-performance employees, so the right people are not always getting hired for the job." 5 As a result, pre-employment testing paves the way for a more thorough and efficient selection of potential job applicants as opposed to only relying on reviewing resumes, applications, and reference/background checks.

Pre-employment testing must be administered with the intent of selecting the most qualified applicants from among applicant pools. Pre-employment testing is not always $100 \%$ accurate and Human Resource managers and hiring managers must realize that all employment assessment tools are subject to error and cannot always accurately predict job performance. Therefore, utilizing effective principles of assessment in pre-employment testing is crucial in order to choose the most qualified candidates.

For instance, to achieve successful pre-employment testing strategies, the employer must be fully clear on what needs to be accomplished and what is expected to be accomplished by using pre-employment assessment tools. In addition, employers should only use pre-employment testing that is appropriate for that particular purpose. Secondly, selecting pre-employment mechanisms that are unbiased and fair to all groups will enable organizations to stay within EEOC and Title VI employment guidelines. Thirdly, employers should only use valid and reliable preemployment testing tools that will provide accurate and consistent scores. This also involves using pre-employment testing tools that are appropriate for the target population (reading levels, language barriers, and cultural backgrounds).

In addition, successful pre-employment testing strategies also encompass that all administrative staff be properly trained, that testing conditions are suitable for all test-takers, that testing scores are interpreted properly, and that confidentiality is maintained at all times during the pre-employment testing process.

Pre-employment testing is broken down into two separate categories of assessment. The first category, psychological screening, assesses levels of skill-based competency, cognitive abilities, and mental attitudes toward performance. The second category of pre-employment testing, physical screening, assesses fitness in performing specific job requirements that includes drug/alcohol testing, and genetic testing. These pre-employment testing categories enable organizations to engage in cost-effective employment strategies that can prevent the organization from absorbing large medical benefit costs if employees have pre-existing conditions that would not normally be detected through a traditional hiring process of merely reviewing resumes/applications, and performing reference check procedures.

Various pre-employment testing methods are available to employers to utilize during their pre-employment hiring process. Psychological testing methods such as the standard paper and pencil tests are broken down into written honesty and personality tests, and skills and aptitude tests. Many of these traditional written tests are now offered on the computer and can be taken via a computer within the employer's testing area.

For instance, computerized candidate profiling is a pre-employment testing tool that is used by Texas New Mexico Power, Optio Software, and Apex Capital to assist in the selection process for salespeople. ${ }^{6}$ A computerized test designed to profile each applicant's personality and thinking structure is conducted. The computerized system compares each applicant's traits to the traits for success on the job and generates a report based upon how well each applicant matches the ideal profile for a particular job. The benefits of this computerized pre-employment testing tool are that it will give recommendations to the employer on specific questions the interviewer should ask, along with specific guidelines for evaluating those applicant's responses. 
This pre-employment testing method is extremely helpful to Human Resource managers and hiring managers because it customizes questions for each applicant and allows the interviewers to delve deeper into the specific traits and tendencies an applicant may possess in order to screen out those applicants that would not be most qualified for positions within the organizations.

Dependability tests are also psychological tests used to forecast an applicant's likelihood to succeed on the job. Lastly, Biodata inventories are standardized questionnaires that collect job-relevant biographical information (job experiences, educational achievements, hobbies) and focus on behavioral aspects of succeeding and job performance.

Drug and alcohol tests are physical testing methods that determine whether an applicant is under the influence of either drugs or alcohol. Because organizations adhere to the fact that drug and alcohol use is illegal within the workforce, organizations may engage in this type of pre-employment testing, especially if the job involves public safety such as an airline pilot or a school bus driver. In addition, it is important to note that drug screening varies within states, and legal ramifications and limitations should be reviewed when engaging in this form of preemployment testing.

Employers should be familiar with the costs associated with this type of testing, as well as the percentages of false positives that could occur within the applicant pool. Organizations can be successful in their applicant selections by engaging in effective pre-employment testing methods that involve valid, reliable testing questions and techniques in order for the organization to not only stay legally compliant, but to also protect itself from unnecessary litigation.

At one time, organizations could hire anyone they desired to hire by totally controlling the interview and selection process. Organizations many years ago, could engage in hiring practices that today, are thought to be unethical and illegal discriminatory measures through their pre-employment strategies when dealing with women and minorities.

Today, federal and state laws have mandated laws in accordance to EEOC regulations and Title VI guidelines that easily send organizations to court if discriminatory violations and unlawful pre-employment selection processes violate the legal rights of protected classes and groups, such as women and minorities. As Richard Pinsker states in his book Hiring Winners, "Candidates have become more than a match for their hiring counterparts. Employers never learned in college how to select employees, and no books provide an easy system to help the employer get back in control.

Today, in many cases, it is the candidate who intimidates and controls the interview." ${ }^{7}$ In this dynamic environment, organizations must protect themselves by engaging in sound, legal pre-employment testing methods that not only enhance the hiring process, but stay within EEOC and Title VI guidelines and regulatory boundaries.

Pre-employment Testing has many advantages to the pre-selection and hiring process. For instance, preemployment testing can uncover potential problems and can aid the hiring process by uncovering all aspects within the hiring process through information collection and analyzing relevant applicant data. It is wise and recommended to have a checklist that lists very important aspects of pre-employment testing and the results uncovered from the data provided. Suggestions include determining whether or not the applicant was honest from the pre-employment testing methods administered. Another suggestion is that employer should determine if the applicant could be trusted. If the answer is no for whatever suspicions or factors that could be pointing in that direction, the employer should determine if the applicant has a clean record on crime and drug/alcohol testing.

Employers should always draft pre-employment questions with their corporate lawyers first before administering such tests in order to stay within legal boundaries. In addition, legally, employers should consult public records for any felony charges. Inquiring about criminal arrests is not legal activity and can lead the organization into litigation. In addition, determining physical health capabilities according to job specifications can ensure employers that applicants are fully capable to perform the required tasks of a position, especially if that position involves physical dexterity and high concentrations of physical coordination and skill. 


\section{ARE EMPLOYERS GETTING AROUND GRIGGS WITH THE SAME TESTING CONCEPTS THAT GRIGGS REQUIRES?}

A number of recent cases demonstrate that employers still have not taken the dictates of the Griggs case to heart. In Saroka V. Dayton Hudson, 235 Cal. App. 3d 654, (1991), a class action invasion-of-privacy and employment discrimination lawsuit was filed on behalf of applicants for security guard positions at Target's 113 California stores. The plaintiff applied for a security guard position with Target Stores and was required to take the California Psychological Inventory (CPA) and the Minnesota Multiphasic Personality Inventory (MMPI). The plaintiff contended that the test questions probed into his private thoughts and deepest feelings and were not job related.

The court agreed that the some of the test questions did indeed invade the applicants' privacy because they asked about religious beliefs and sexual preferences.

Among the true/false questions were:

- $\quad$ I believe my sins are unpardonable.

- I I am very attracted to members of my own sex.

- $\quad$ Evil spirits possess me sometimes.

- $\quad$ I have no difficulty starting or holding my bowel movement.

- $\quad$ My sex life is satisfactory.

- I have never been in trouble because of my sexual behavior.

- I I feel sure there is only one true religion.

- $\quad$ I go to church almost every week.

Target needed to show some compelling reasons for the invasion of privacy and demonstrate that the test served a job related purpose to justify that invasion of privacy. While the court acknowledged that Target had an interest in employing emotionally stable persons as security officers, Target did not show how information pertaining to an applicant's sexual preferences or religious beliefs would have any bearing on emotional stability. Therefore the questions were deemed as not being job-related. Target settled the lawsuit for over $\$ 2$ million without admitting wrongdoing or liability.

In another case, Karraker v. Rent-A-Center, 316 F. Supp. 2d 675 (CD Ill. 2004), the Karraker brothers brought a class action against Rent-A-Center alleging violations of the ADA after the three brothers were denied promotions because they failed the APT Management Trainee-Executive Profile. The APT was a series of 9 tests designed to measure such things as math and language skills as well as personal interests and personality traits.

Part of the test was taken from the Minnesota Multi-Phasic Personality Inventory. Rent-A-Center argued the MMPI portion of the test measured simply whether someone works well in groups or is comfortable in a fast-paced office. The court noted, however, that the MMPI measures traits such as depression, hypochondrias, hysteria, paranoia and mania. Elevated scores on portions of the MMPI can also be used to diagnosis psychiatric disorders.

Rent-A-Center, however, took the position that the MMPI was a personality test permitted by the Equal Employment Opportunity Commission's enforcement guidance, not a prohibited medical examination (The MMPI has 2 sets of criteria - one a clinical set and one non-clinical). Rent-A-Center, thus, asked the court to find the MMPI was not a medical examination and, thus, not regulated by the ADA. In making that request, however, Rent-A-Center conceded a key point.

The plaintiffs took the position that the MMPI was being used as a pre-employment medical examination and was illegal as a matter of law. The court noted Rent-A-Center could have argued that the test was an evaluation tool used during employment rather than a pre-employment screening device. 
Performance tests and evaluations that are "job related and consistent with business necessity" are legal under the ADA. In other words, Rent-A-Center could have taken the position that an employee's application for a promotion merely served as the occasion to administer the test and that the employer used it merely as a tool to assign the right employee to the right job.

Conceivably, under that theory, the MMPI would not simply screen out unsuitable employees, but it might also reveal the exceptional employee misassigned to lower grade position. Rent-A-Center, however, gave up that argument by agreeing with the plaintiffs that the MMPI was a pre-employment test.

The court held Rent-A-Center's use of the MMPI was illegal because it measured traits that are not relevant to promotion. The court noted that psychological tests designed to identify a medical disorder or impairment qualify as medical examinations, but psychological tests that measure personal traits such as honesty, preferences and habits do not. Rent-A-Center's use of the MMPI could reveal mental disorders or impairments such as depression.

Rent-A-Center's explanation for this point, however, did not pass muster with the Court:

RAC argues in its brief that the MMPI does not test whether an applicant is clinically depressed, only 'the extent to which the test subject is experiencing the kinds of feelings of depression that everyone feels from time-to-time (e.g., when their favorite team loses the World Series).' Although that particular example seems odd to us (can an Illinois chain really fill its management positions if it won't promote disgruntled Cubs' fans?), the logic behind it doesn't seem to add up, either. ... [Rent-A-Center] suggested that an applicant might, for example, score high on the depression scale because he lost his keys that morning. But why would RAC care if an applicant lost his keys the morning of the MMPI or took the test the day after another Cubs' loss? Would RAC really want to exclude an employee from consideration for a promotion because he happened to feel sad on the wrong day?

\section{THE RISK FOR EMPLOYERS}

The risk for employers in using inappropriate testing and in failing to follow the Griggs standard is to face lawsuits from disgruntled employees or individuals not hired. With the advent of class action lawsuits increasing damages and costs, employers need to focus on the legalities of pre-employment testing, not only as a defensive measure, but in order to hire employees who will be successful in their job performance.

\section{CONCLUSION}

Pre-employment testing is shaping the way American businesses hire qualified, successful, and performancedriven employees. Pre-employment testing strategies and methods, coupled with a comprehensive preselection/hiring process will ensure that the most qualified candidates are chosen and not overlooked in today's dynamic and ever-changing workforce.

As Clinton Longenecker and Jack Simonetti, state in their book Getting Results, "Practice progressive staffing to ensure that your operation has the right people, in the right positions, with the right skills, at the right time. These practices include effective human resource planning, excellent selection practices, and effective work schedules." ${ }^{\text {8 }}$ Organizations must ensure that their pre-selection and hiring processes are up-to-date with all EEOC regulations and guidelines and that all pre-employment testing methods are updated in accordance with these regulations as well in order to maximize effective hiring selection. ${ }^{9}$

Pre-employment testing has shown that personality and human behavioral traits analysis are crucial in determining how an individual reacts within his/her working environment. These predictors can enable organizations to utilize this information in the most beneficial way in order to maximize the best employee selection possible. With all of the governmental laws and regulations such as EEOC, Title VI, the Americans with Disabilities Act, and the Fair Credit and Reporting Act, employers have to protect themselves against unlawful and unfair employment processes that at one time, were not a consequence at all. ${ }^{10}$ It is more than necessary in today's society to implement 
sound pre-employment testing methods in order to narrow down the criteria necessary to make good informed employment decisions.

Pre-employment testing is one tool within the pre-employment selection process that can effectively and efficiently provide valid and reliable predictors of successful performance and is a vital key in effective human resource management.

\section{Timeline}

- $\quad 1856-1939-$ Sigmund Freud

Founder of the psychoanalytic school of psychology

- $\quad 1870-1937$ - Alfred Adler

Founder of the school of individual psychology

- $\quad 1878-1958-$ John B. Watson

Founder of the psychological school of behaviorism

- $\quad 1875$ - 1961 - Carl Jung

Founder of the school of analytical psychology

- 1915 - Carnegie Institute of Technology in their Applied Psychology Division and a year later in their Bureau of Salesmanship Research use psychometrics, the study and science of personality, in the workplace.

- $\quad 1917$ - 1918 - the United States Military begins utilizing personality testing to weed out applicants not suitable for combat

- 1920's and 1930's - paper and pencil personality tests, such as Gordon Allport's Ascendance-Submission Test and the Bernreuter Personality Inventory, become common.

- $\quad 1908$ - 1970 - Abraham Maslow

Creator of the Hierarchy of Human Needs

1942 - Original Minnesota Multiphasic Personality Inventory developed at the University of Minnesota. The original authors were Starke R. Hathaway, PhD, and J. C. McKinley, MD

- $\quad 1903$ - 1998 - Benjamin Spock

First pediatrician to study psychoanalysis to understand children and family dynamics.

- 1964 - The Civil Rights Act of 1964 (Pub.L. 88-352, 78 Stat. 241, July 2, 1964). [Also known as "Title VII"]

Landmark legislation that outlawed employment discrimination based on race, color, religion, sex, or national origin.

- 1971 - Griggs v. Duke Power Company, 401 U.S. 424 (1971). The US Supreme Court rules that if employment tests disparately impact ethnic minority groups, businesses must demonstrate that such tests are "reasonably related" to the job for which the test is required. Title VII of the Civil Rights Act prohibits employment tests (when used as the controlling factor in employment decisions) that are not a "reasonable measure of job performance," Griggs also held that the employer has the burden of producing and proving the business necessity

- 1989 - Patterson v. McLean Credit Union, 491 U.S. 164 (1989)

[An employee could not sue for damages caused by racial harassment on the job]

Wards Cove Packing Co. v. Atonio, 490 U.S. 642 (1989) [Made it more difficult for employees to prove that an employer's personnel practices, neutral on their face, had an unlawful disparate impact on them by requiring that they identify the particular policy or requirement that allegedly produced inequalities in the workplace and show that it, in isolation, had this effect.]

Price Waterhouse v. Hopkins, 490 U.S. 228 (1989) [Burden of proof shifted, once an employee had proved that an unlawful consideration had played a part in the employer's personnel decision, to the employer to prove that it would have made the same decision if it had not been motivated by that unlawful factor, but that such proof by the employer would constitute a complete defense for the employer.]

Martin v. Wilks, 490 U.S. 755 (1989) [Permitted white firefighters who had not been party to the litigation establishing a consent decree governing hiring and promotion of black firefighters in the Birmingham, Alabama Fire Department to bring suit to challenge the decree ] 
- 1991 - Civil Rights Act of 1991 (Pub. L. 102-166), as enacted on November 21, 1991, which amended the 1964 Civil Rights Act

Saroka V. Dayton Hudson, 235 Cal. App. 3d 654, (1991) [A class action invasion-of-privacy and employment discrimination lawsuit was filed on behalf of applicants for security guard positions at Target's 113 California stores.]

- 2004 - Karraker v. Rent-A-Center, 316 F. Supp. 2d 675 (CD Ill. 2004) [Use of the MMPI illegal because it measured traits that are not relevant to promotion]

\section{ENDNOTES}

1. Kleiman, Mel, Hire Tough - Manage Easy: How to Find and Hire the Best Hourly Employees (HTG Press, a Division of Humetrics, Inc., 1999)

2. Hoffman, Edward PhD, Psychological Testing at Work, (McGraw-Hill, 2002

3. Hoffman, Edward PhD, Psychological Testing at Work, (McGraw-Hill, 2002)

4. Messner, Max, The Fast Forward MBA in Hiring: Finding and Keeping the Best People (New York: John Wiley \& Sons, Inc., 1998)

5. Podmoroff, Dianna How to Hire, Train and Keep the Best Employees for your Small Business (Atlantic Publishing Group, Inc., 2005)

6. Griffin, Ricky W., Management, $7^{\text {th }}$ Edition (Houghton Mifflin Company, 2002)

7. Pinsker, Richard Hiring Winners, Profile Interview Evaluate: a 3-Step Formula for Success (AMACON, a Division of American Management Association, 1991)

8. $\quad$ Longenecker, Clinton O. and Simonetti, Jack L., Getting Results (John Wiley \& Sons, Inc., 2001)

9. $\quad$ Rudner, Lawrence M. Public Personnel Management Vol. 21 (1992)

10. Wilson, Hugh Steven A Second Look at Griggs v. Duke Power Company: Ruminations on Job Testing, Discrimination, and the Role of the Federal Courts Virginia Law Review, Vol. 58, No. 5 (May, 1972), pp. 844-874 